Jejaring Administrasi Publik, Vol. 13, No. 1, 2021, hal 49-58

\title{
Pemberdayaan Dikalangan Calon Pekerja Migran Dalam Rangka Pencegahan Penyakit Menular di Desa Benculuk, Kecamatan Celuring, Kabupaten Banyuwangi Jawa Timur
}

\author{
Empowerment Among Prospective Migrant Workers in the Context of \\ Preventing Infectious Diseases in Benculuk Village, Celuring District, \\ Banyuwangi Regency, East Java
}

\author{
Toetik Koesbardiati ${ }^{1}$, Sri Endah Kinasih ${ }^{2}$, Delta Bayu Murti ${ }^{3}$, Rachmah Ida ${ }^{4}$, Irfan \\ Wahyudi ${ }^{5}$ \\ 1,2,3,4,5Fakultas Ilmu Sosial dan Ilmu Politik, Universitas Airlangga \\ E-mail: sriendah.kinasih@fisip.unair.ac.id
}

\begin{abstract}
The low level of Indonesian Migrant Workers is actually directly correlated with their low level of formal education. The average formal education is $68 \%$ of elementary and junior high school graduates. PMI knowledge related to disease transmission due to interaction patterns is very low. Infectious diseases in PMI related to interaction patterns are mostly carried out in destination countries. This study discusses empowerment among prospective migrant workers in the context of preventing infectious diseases in Benculuk village, Celuring sub-district, Banyuwangi district, East Java. This study was conducted at the Indonesian Migrant Workers Union in Benculuk Village, Cluring District, Banyuwangi, East Java Province. The location of the research was determined purposively in Banyuwangi district, which is one of the seven districts in East Java that sends migrant workers abroad. Data collection includes observation and in-depth interviews. The selected informants are individuals who have knowledge and experience about the problems studied. The last is data analysis, namely the data collected and then classified and identified based on the theme and then analyzed with qualitative data analysis. The results of this study indicate that PMI candidates do not yet have knowledge about infectious diseases caused by inappropriate interactions. Proper interaction will prevent disease transmission. Moreover, information on disease transmission was not conveyed during the Final Departure Briefing and was not supported by using teaching media such as videos, simulations and only using the lecture method. Thus, the material presented is not in accordance with the instructor's grip module. With the empowerment of PMI candidates related to the dangers of infectious diseases, it is necessary to have tips to avoid it by limiting interactions in the destination country.
\end{abstract}

Keywords: migrant workers, disease transmission, empowerment 


\title{
Koesbardiati, dkk: " Pemberdayaan Dikalangan Calon Pekerja Migran Dalam Rangka Pencegahan Penyakit Menular"
}

\begin{abstract}
Abstrak
Rendahnya Pekerja Migran Indonesia sebenarnya berkorelasi lurus dengan rendahnya tingkat pendidikan formal mereka. Rata-rata pendidikan formal sebanyak $68 \%$ lulusan SD dan SMP. Pengetahuan PMI terkait dengan penularan penyakit yang disebabkan adanya polapola interaksi sangatlah rendah. Penyakit menular pada PMI terkait dengan pola-pola interkasi banyak dilakukan di negara tujuan. Studi ini membahas tentang pemberdayaan dikalangan calon pekerja migran dalam rangka pencegahan penyakit menular desa Benculuk, kecamatan Celuring, kabupaten Banyuwangi Jawa Timur. Studi ini dilakukan pada Serikat Buruh Migran Indonesia Desa Benculuk Kecamatan Cluring Banyuwangi Provinsi Jawa Timur. Penentuan lokasi penelitian ditentukan secara purposive di kabupaten Banyuwangi merupakan salah satu kabupaten dari tujuh kabupaten di Jawa Timur pengirim pekerja migran ke luar negeri. Pengumpulan data meliputi observation dan indepth interview. Informan yang dipilih adalah individu-individu yang memiliki pengetahuan dan pengalaman tentang permasalahan yang diteliti. Terakhir adalah analisa data yaitu data yang terkumpul kemudian diklasifikasikan dan diindentifikasikan berdasarkan tema kemudian dianalisa dengan analisis data kualitatif. Hasil studi ini menunjukkan bahwa calon PMI belum memiliki pengetahuan tentang penyakit menular yang disebabkan oleh interaksi yang tidak tepat. Interkasi yang tepat akan mencegah terjadinya penularan penyakit. Apalagi informasi penularan penyakit tidak disampaikan pada pelaksanaan Pembekalan Akhir Pemberangkatan dan tidak didukung dengan menggunakan media pengajaran seperti video, simulasi dan hanya menggunakan metode ceramah. Demikian materi yang disampaikan tidak sesuai dengan modul pegangan instruktur. Dengan adanya pemberdayaan dikalangan calon PMI terkait dengan bahaya penyakit menular perlu adanya kiat-kiat untuk menghindarinya dengan membatasi interaksi di negara tujuan.
\end{abstract}

Kata kunci: pekerja migran, penularan penyakit, pemberdayaan

\section{Pendahuluan}

Migrasi dan penyakit selalu berjalan seiringan dan saling terkait ketika sekelompok orang melakukan migrasi maka disaat itulah terjadi penyebaran penyakit. Perpindahan penyakit selalu diikuti perpindahan manusia. Penyakit menular pada PMI terkait dengan pola-pola interaksi yang dilakukan di negara tujuan. Hal ini tentunya berdampak pada penyebaran penyakit menular pada PMI purna penempatan yang semakin meningkat bahkan menyebarluas bukan hanya di daerah pengiriman saja tetapi ke wilayah-wilayah yang bukan pengiriman PMI. 
Studi (Beay, Kasbawati, \& Toaha, 2017; Wang \& Wang, 2012) menjabarkan bahwa model migrasi yang berlangsung dalam suatu komunitas dapat menciptakan penularan penyakit. Sebenarnya pekerja migran ini menghasilkan kontribusi yang besar bagi pembangunan ekonomi di negara tujuan, namun disisi lain juga membuat masalah sosial yang salah satunya penyakit menular.

Penyakit menular yang disebabkan oleh migrasi adalah TB, HIV, dan hepatitis B dan C (Seedat et al., 2018), penyakit malaria (Beay et al., 2017), Helicobacter pylori, patogen lambung kronis manusia (Falush et al., 2003), penyakit kusta (Monot et al., 2005), Campylobacter jejuni penyebab utama dari bakteri gastro-enteritis (Wilson et al., 2008), Severe Acute Respiratory Syndrome (SARS), Middle East Respiratory Syndrome (MERS), malaria, schistosomiasis, West Nile, Dengue, Chikungunya, maupun TBC Vignier (Vignier \& Bouchaud, 2018), N., \& Bouchaud, O. (2018), COVID-19 (WHO, 2020).

Menurut Vignier dan Bouchaud (2018) menjelaskan Emerging Infectious Diseases (EIDs), penyakit menular mengancam masyarakat global health akibat dari pola-pola interaksi, kemiskinan, perdagangan global dan migrasi. Migrasi sebagai penyebab EIDs dan menjadi awal terjadinya epidemi.

Pemberitaan Kompas, 26 September 2012, terkait dengan SARS merupakan contoh nyata mudahnya penyebaran penyakit akibat dari migrasi manusia dengan sarana transportasi modern. Akhir Desember 2019 dan awal tahun 2020 ini Novel Coronavirus yang dikenal dengan COVID-19 kelompok virus baru teridentifikasi telah melanda 82.294 individu di seluruh dunia, dengan jumlah penderita terbesarnya di Tiongkok (WHO, 2020a)

Distribusi penyebaran penyakit disebabkan oleh migrasi. Sebaran COVID-19 dapat dilihat pada gambar dibawah ini. 


\section{Koesbardiati, dkk: " Pemberdayaan Dikalangan Calon Pekerja Migran Dalam}

Rangka Pencegahan Penyakit Menular"

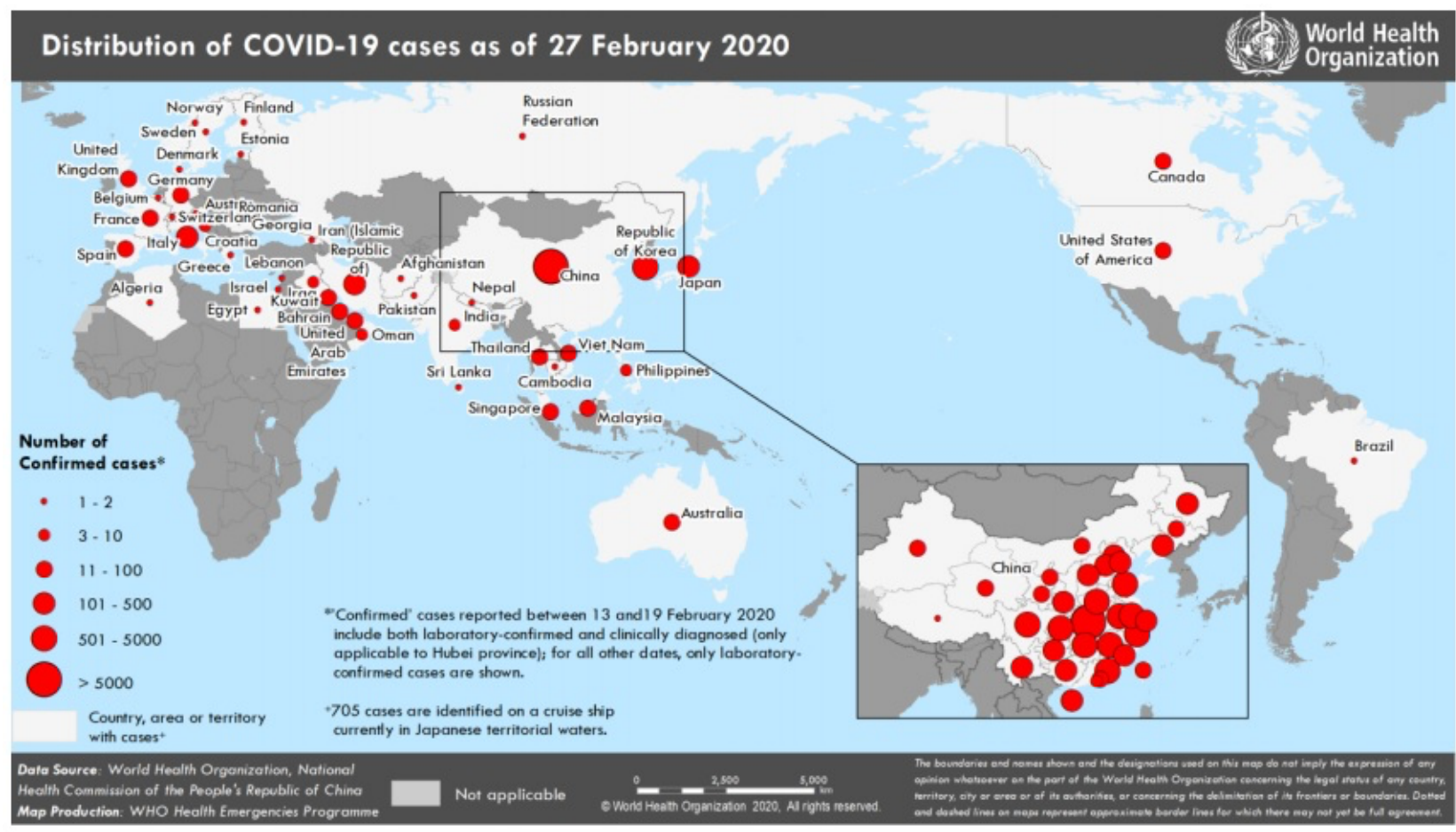

Gambar 1

Distribusi COVID-19 per 27 February 2020

Sumber : (WHO, 2020b)

Distribusi ini penyebaran Covid 19, sangat erat dikaitkan dengan pola-pola interaksi manusia yang dihubungkan dengan migrasi.

Laporan WHO dari Komisi Migrasi dan Kesehatan yang didirikan pada tahun 2016 (Abubakar et al., 2016), bertujuan untuk mengidentifikasi arah kebijakan yang sering kali menyampingkan kebutuhan dan kerentanan para migran. Komisi ini memberikan rekomendasi menuju Global Health dengan misi migrasi sehat. Para migran tetap hidup dalam kondisi tanpa hak, perawatan kesehatan sebagai hak asasi manusia.

Data dari suarabmi Banyuwangi dari tahun 2006 sampai 2017, masyarakat Banyuwangi sekitar 2.246 positif terinveksi HIV/AIDS, diantaranya 112 PMI. Hal ini menjadi sangat penting karena Indonesia merupakan salah satu penyumbang pekerja migran yang cukup besar di dunia. PMI yang teridentifikasi HIV/AIDS, hingga saat ini saja tidak pernah diketahui secara pasti. Padahal mereka kerap diidentifikasi sebagai kelompok yang rentan disergap penyakit ini. Malah, yang cukup mencengangkan ternyata masih ada anggapan HIV/AIDS adalah penyakitnya "orang nakal" atau 
orang yang berprofesi sebagai pekerja seks komersial. Akibatnya, upaya penanggulanganpun dilakukan tidak secara kontinu dan tidak sistematis. Saat ini penyuluhan HIV/AIDS sepertinya masih terfokus kepada pekerja seks komersial atau pencandu narkoba daripada kepada PMI.

Rendahnya pengetahuan PMI sebenarnya berkorelasi lurus dengan rendahnya tingkat pendidikan formal mereka. Hal ini terkait latar belakang tingkat pendidikan menjadi PMI mayoritas tamatan SD dan SMP sebanyak 68\% atau sekitar 179. 869 orang. Sisanya lulusan SMA 79.899 orang (30\%), lulusan Diploma 3.079 orang (1.2\%), hanya $0.8 \%$ sebarannya di lulusan sarjana dan pascasarjana (BP2MI, 2020). Temuan studi Irianto et al. (2011) di Uni Emirat mengkonfirmasi bahwa 8 diantara 57 orang yang berada di Abu Dhabi adalah buta huruf yaitu sekitar 90\% di antara mereka lulusan Sekolah Dasar .

Pengetahuan PMI terkait dengan penularan penyakit yang disebabkan adanya polapola interaksi karena kurangnya materi tersebut. Materi PAP terdapat 11 item dengan total 18 jam pelajaran berdurasi 45 menit setiap jam pelajaran. Materi tersebut merupakan materi tentang kompetensi yang harus dilakukan sesuai dengan jenis pekerjaannya. Misalnya PMI tersebut memilih pekerja rumah tangga materinya tentunya berbeda dengan pengasuh anak atau lansia. Materi-materi tersebut diberikan saat proses PAP di seluruh Balai Pelayanan PenempatanTKI (BP2TKI) yang ada di Indonesia. Pengetahuan dasar seputar HIV/AIDS, kesehatan reproduksi, dan juga penyakit menular lainnya hampir tidak pernah diberikan.

Dari hal inilah, studi ini membahas tentang pemberdayaan dikalangan calon pekerja migran dalam rangka pencegahan penyakit menular Desa Benculuk, Kecamatan Celuring, Kabupaten Banyuwangi Jawa Timur perlu untuk dikembangkan. .

\section{Metode Penelitian}

Penentuan lokasi penelitian ditentukan secara purposive di kabupaten Banyuwangi merupakan salah satu kabupaten dari tujuh kabupaten di Jawa Timur pengirim pekerja migran ke luar negeri. Jawa Timur selama tiga tahun berturut-turut dari tahun 2017 sampai tahun 2019 merupakan provinsi tertinggi dari 34 provinsi di Indonesia dalam hal pengiriman PMI nya. Dalam tiga tahun terakhir, akumulasi PMI Jawa Timur sebesar 167.933 orang, disusul dengan Jawa Tengah 160.644 orang dan Jawa Barat 156.631 orang. Di Jawa Timur, terdapat tujuh kabupaten terbesar penyumpang penempatan PMI yaitu Banyuwangi, Ponorogo, Blitar, Malang, Banyuwangi, Madiun dan Kediri. 


\section{Koesbardiati, dkk: " Pemberdayaan Dikalangan Calon Pekerja Migran Dalam Rangka Pencegahan Penyakit Menular"}

Untuk mendapatkan data, penelitian ini menggunakan Focus Group Discussion (FGD) dilakukan dengan mitra yaitu PMI purna, SBMI, ILO, BP2MI, kepala desa, pondok pesantren dan PJTKI untuk melakukan pendataan sekaligus review atas kasus-kasus penyakit menular selama ini di Banyuwangi.

Setelah mendapatkan data, maka selanjutnya tahap kedua mulai menghadirkan persoalan riil dampak dari pola interaksi dan perilaku yang menyebabkan terjadinya penularan penyakit pada PMI. Untuk itu diperlukan identifikasi siapa saja yang dirasa cukup mewakili untuk dihadirkan dalam penelitian ini yang sifatnya peer to peer. Penelitian beserta SBMI akan melakukan identifikasi peer group dan melakukan persuasi terhadap kelompokkelompok sasaran yang akan dijadikan peer group.

Setelah peer group sudah teridentifikasi dan bersedia untuk ikut aktif terlibat dalam FGD untuk mengidentifikasi pola-pola berkomunikasi ketika sampai ke negara tujuan dan upaya-upaya yang dilakukan dalam melakukan penolakan ketika dalam interaksi berdampak pada kesehatan mereka.

Penelitian ini juga menggunkan observation dan indepth interview. Informan yang dipilih adalah individu-individu yang memiliki pengetahuan dan pengalaman tentang permasalahan yang diteliti. Terakhir adalah analisa data yaitu data yang terkumpul kemudian diklasifikasikan dan diindentifikasikan berdasarkan tema kemudian dianalisa.

\section{Hasil Pembahasan}

Negara yang dituju para PMI asal Banyuwangi sangat bervariasi seperti Malaysia, Singapura, Taiwan dan Timur Tengah sehingga mereka rentan terjangkit penyakit menular yang di masing-masing negara tujuan mempunyai ciri khas tertentu. Setiap negara yang ditempati pekerja migran itu mempunyai variasi penyakit yang tentu tidak sama dengan negara lain sehingga calon pekerja migran harus lebih waspada dengan negara yang akan dituju. Misalnya Mers di negara-negara Timur Tengah, flu burung dan COVID-19 di negara Cina, penyakit kulit di Malaysia yang menular karena banyak PMI yang ditempatkan di negara tujuan. Hasil FGD ini akan dijadikan data yang kemudian bisa diinformasikan kepada calon pekerja migran terkait bahaya penyakit menular dan kiat-kiat menghindarinya.

Calon PMI perlu mendapat pemberdayaan soal bahaya penyakit menular di negara tujuan berikut kiat-kiat untuk menghindarinya. Community empowernment atau pemberdayaan masyarakat merupakan proses memaksimalkan kemampuan suatu komunitas dalam masyarakat sebagai upaya untuk mengakses sumberdaya untuk memperbaiki kualitas hidup individu dalam komunitas tersebut. Intinya pemberdayaan masyarakat lebih kepada 


\section{Jejaring Administrasi Publik, Vol. 13, No. 1, 2021, hal 49-58}

proses yang terencana dan terukur pada komunitas rentan supaya mempunyai kemampuan untuk melakukan tindakan tertentu (Adamson \& Bromiley, 2008; Craig \& Mayo, 1995). Upaya pemberdayaan masyarakat menganut prinsip berikut: (1) melakukan gerakan, yaitu mengikutsertakan unsur-unsur anggota masyarakat yang diberdayakan (2) memiliki dampak, artinya aktivitas yang dilakukan memberikan manfaat pada komunitas rentan, (3) holistik, artinya aktivitas yang dilakukan harus berkaitan dengan aktivitas yang lainnya (Williams \& Labonte, 2007; Yang, Zhang, \& Liu, 2006). Pemberdayaan ini sangat penting dan sangat dibutuhkan bagi calon PMI, apalagi dalam masa pandemi COVID-19 karena PMI sebagian besar bekerja di sektor yang penuh risiko, yaitu sektor 3D, difficult (sulit), dirty (kotor), dan dangerous (bahaya) yang minim proteksi.

Pemberdayaan itu membangun kesadaran kritis dengan melibatkan unsur-unsur anggota masyarakat untuk mencapai tujuan yang diharapakan. Kesadaran kritis inilah akan menjadi sebuah kreator bagi komunitasnya dengan memiliki komitmen untuk mengubahnya (Munawaroh, 2019). Kesadaran kritis merupakan penggerak komunitas untuk mau melakukan perubahan besar dan bermakna. Perubahan besar dan bermakna akan menambah pengetahuan praktikal upaya menyelesaikan masalah yang dihadapi. Kesadaran kritis saling berkaitan dengan pemberdayaan masyarakat.

Pemberdayaan ini mestinya juga dilakukan pemerintah daerah untuk memaksimalkan proses pemberian pengetahuan secara terus menerus dalam pembekalan bagi calon PMI. Pemerintah mestinya juga harus menyediakan media yang mudah diakses oleh PMI seputar aturan dan langkah/SOP ketika ada PMI yang sakit atau terjangkit penyakit menular. Pemerintah juga perlu memberikan proteksi dalam bentuk jaminan sosial bagi PMI sehingga mereka bisa klaim kompensasi jaminan sosial ketenagakerjaan dan jaminan kesehatan perawatan medis. Selain itu, pemerintah Indonesia juga harus melakukan upaya diplomasi di negara tempat bekerja PMI guna membangun mekanisme pelayanan pelindungan bagi PMI migran yang adil, mudah diakses, dan cepat untuk penyelamatan, repatriasi, penyelesaian dan pembayaran klaim jaminan sosial pekerja migran yang mengalami sakit.

Pemberdayaan juga melalui pembuatan video edukatif yang mendokumentasikan realitas sebagai cara untuk menghadirkan persoalan riil yang terjadi melalui perspektif PMI purna tugas dalam berperilaku dan berinteraksi. Video edukatif ini penting dibuat sebagai pengingat dan upaya untuk menyadarkan calon PMI bahwa fenomena ini memanglah fakta yang benar-benar terjadi sehingga tidak ada pihak yang menutup mata atau merasa tidak mengetahui permasalahan tersebut. Video edukatif ini nantinya memuat informasi dalam berperilaku dan berinteraksi mengenai alasan yang mendorong mereka harus berperilaku dan 


\section{Koesbardiati, dkk: " Pemberdayaan Dikalangan Calon Pekerja Migran Dalam Rangka Pencegahan Penyakit Menular"}

berinteraksi seperti apa sehingga tidak terjadinya penularan penyakit dan bagaimana cara mengatasinya, jika terjadi berperilaku dan berinteraksi berdampak pada penularan penyakit. Produksi video edukasi ini dilakukan oleh PMI purna tugas untuk mendapatkan narasi-narasi cultural dari perspektif PMI. Pemberdayaan ini bertujuan agar mereka menyadari bahwa dalam berperilaku dan berinteraksi melebihi batas-batas kesehatan lebih banyak memunculkan persoalan penyakit menular.

Video edukatif menyampaikan pesan konten-konten situasi bekerja mereka dan mengkampanyekan perilaku hidup bersih dan kiat-kiat agar terhindar dari penyakit menular. Strategi kampanye menggunakan bahasa-bahasa yang digunakan dalam video edukatif adalah bahasa Indonesia yang mudah dipahami sesuai dengan target sasaran. Harapannya mereka bisa mengaplikasikannya ketika mereka berada di negara tujuan.

Konten dalam video edukatif dibuat karena akan menjadi media kampanye yang mudah diakses dan mudah dipahami. Video edukatif tersebut berupa karya audio-visual dalam bentuk kampanye yang berisikan kisah, baik melalui penuturan langsung PMI dan PJTKI, maupun yang dinarasikan dalam bentuk voice-over. Video edukatif ini dibuat dengan durasi yang sangat singkat agar mudah diunggah di media sosial dan dapat ditonton dalam waktu yang singkat.

Video edukatif ini ditujukan untuk komunitas yang ada di SBMI itu sendiri dan dilinkkan dengan website LPPM. Video edukatif ini bisa juga dipergunakan sebagai branding Lembaga Pengabdian dan Pengembangan Masyarakat (LPPM) dengan dikemas begitu menarik yang dapat meningkatkan webometrik Universitas Airlangga.

\section{Kesimpulan}

Calon PMI perlu mendapat pemberdayaan soal bahaya penyakit menular di negara tujuan berikut kiat-kiat untuk menghindarinya. Pemberdayaan ini sangat penting dan sangat dibutuhkan bagi calon PMI, apalagi dalam masa pandemi COVID-19 karena PMI sebagian besar bekerja di sektor yang penuh risiko, yaitu sektor 3D, difficult (sulit), dirty (kotor), dan dangerous (bahaya) yang minim proteksi.

1. Kegiatan edukasi ini mestinya juga dilakukan pemerintah daerah untuk memaksimalkan proses pemberian pengetahuan secara terus menerus dalam pembekalan bagi calon PMI. Pemerintah mestinya juga harus menyediakan media yang mudah diakses oleh PMI seputar aturan dan langkah/SOP ketika ada PMI yang sakit atau terjangkit penyakit menular. Pemerintah juga perlu memberikan proteksi dalam bentuk jaminan sosial bagi 
PMI sehingga mereka bisa klaim kompensasi jaminan sosial ketenagakerjaan dan jaminan kesehatan perawatan medis. Selain itu, pemerintah Indonesia juga harus melakukan upaya diplomasi di negara tempat bekerja PMI guna membangun mekanisme pelayanan pelindungan bagi PMI yang adil, mudah diakses, dan cepat untuk penyelamatan, repatriasi, penyelesaian dan pembayaran klaim jaminan sosial pekerja migran yang mengalami sakit.

\section{Daftar Pustaka}

Abubakar, I., Devakumar, D., Madise, N., Sammonds, P., Groce, N., Zimmerman, C., Horton, R. (2016). UCL-Lancet Commission on Migration and Health. Lancet, 388(10050), 1141-1142.

Adamson, D., \& Bromiley, R. (2008). Community empowerment in practice. Lessons from Communities First.

Beay, L. K., Kasbawati, \& Toaha, S. (2017). Effects of human and mosquito migrations on the dynamical behavior of the spread of malaria. Paper presented at the AIP Conference Proceedings.

BP2MI. (2020). Data Penempatan dan Pelindungan PMI Periode Desember 2020. Pusat Data dan Informasi, BP2MI, Jakarta.

Craig, G., \& Mayo, M. (1995). Community empowerment: A reader in participation and development: Zed Books.

Falush, D., Wirth, T., Linz, B., Pritchard, J. K., Stephens, M., Kidd, M., . . Perez-Perez, G. I. (2003). Traces of human migrations in Helicobacter pylori populations. Science, 299(5612), 1582-1585.

Irianto, S., Irzan, H., Meij, L. S., Wirastri, T. D., Parikesit, T., Kartika, T., \& Perkasa, V. D. (2011). Akses Keadilan dan Migrasi Global: Kisah Perempuan Indonesia Pekerja Domestik di Uni Emirat Arab: Yayasan Pustaka Obor Indonesia.

Monot, M., Honoré, N., Garnier, T., Araoz, R., Coppée, J.-Y., Lacroix, C., . . Williams, D. L. (2005). On the origin of leprosy. Science, 308(5724), 1040-1042.

Munawaroh, K. (2019). Community Empowerment Model Through Optimization Of The Role Of Indonesian Migrant Workers (PMI) Purna In Encouraging Achievement Of 


\section{Koesbardiati, dkk: " Pemberdayaan Dikalangan Calon Pekerja Migran Dalam Rangka Pencegahan Penyakit Menular"}

The Sustainable Development Goal In East Lampung Regency. Jurnal Ilmiah Administrasi Publik dan Pembangunan, 10 (1).

Seedat, F., Hargreaves, S., Nellums, L. B., Ouyang, J., Brown, M., \& Friedland, J. S. (2018). How effective are approaches to migrant screening for infectious diseases in Europe? A systematic review. The Lancet infectious diseases, 18(9), e259-e271.

Vignier, N., \& Bouchaud, O. (2018). Travel, migration and emerging infectious diseases. EJIFCC, 29(3), 175.

Wang, L., \& Wang, X. (2012). Influence of temporary migration on the transmission of infectious diseases in a migrants' home village. Journal of theoretical biology, 300, 100-109.

WHO. (2020a). Clinical Management of Severe Acute Respiratory Infection When Novel Coronavirus (2019-nCoV) Infection Is Suspected: Interim Guidance.

WHO. (2020b). Coronavirus disease 2019 (COVID-19): situation report, 72.

Williams, L., \& Labonte, R. (2007). Empowerment for migrant communities: Paradoxes for practitioners. Critical Public Health, 17(4), 365-379.

Wilson, D. J., Gabriel, E., Leatherbarrow, A. J., Cheesbrough, J., Gee, S., Bolton, E., . Diggle, P. J. (2008). Tracing the source of campylobacteriosis. PLoS genetics, 4(9).

Yang, H.-1., Zhang, X.-f., \& Liu, T.-r. (2006). On the Empowerment of Migrant Workers [J]. Journal of China Institute of Industrial Relations, 5. 